\title{
The Effect of Peer Support from Mothers of Children with Acute Lymphoblastic Leukemia on Quality of Life of Patients
}

Fereshteh Ghaljaei ${ }^{1}$, Sedigheh Fooladi ${ }^{2}$, Azam Jamali ${ }^{* 3}$, Nasrin Mahoodi ${ }^{4}$, Bahare Zarei ${ }^{\mathbf{5}}$

1. Associate Professor, Community Nursing Research Center and Pediatric Department, Faculty of Nursing and Midwifery, Zahedan University of Medical Sciences, Zahedan, Iran

2. MSc in Pediatric Nursing, Faculty of Nursing and Midwifery, Zahedan University of Medical Sciences, Zahedan, Iran

3. MSc in Pediatric Nursing, Faculty of Nursing and Midwifery, Zahedan University of Medical Sciences, Zahedan, Iran

4. Instructor, Community Nursing Research Center, Faculty of Nursing and Midwifery, Zahedan University of Medical Sciences, Zahedan, Iran

5. Instructor, Department of Nursing Education, Faculty of Nursing and Midwifery, Birjand University of Medical Sciences, Birjand, Iran

Article Info

Received: 2020/01/03;

Accepted: 2020/03/25;

Published Online: 2020/08/22

10.30699/ajnmc.28.3.171

Original Article

Use your device to scan and read the article online

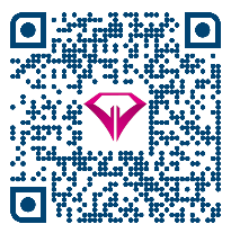

\section{ABSTRACT}

Introduction: Caring for a child with cancer can be deeply frustrating for parents with high levels of anxiety and psychological distress. Parents who suffer from high psychological stress have poorer performance in the family and health-related quality of life in their children is significantly lower. Previous research has demonstrated the effectiveness of peer support in reducing levels of parental psychological distress. This study was aimed to investigate the effect of peer support of mothers of children with acute lymphoblastic leukemia (ALL) on quality of life of patients.

Methods: This is a quasi-experimental study which was performed on 74 mothers of children with ALL hospitalized in Hematology ward of Ali ibn Abi Talib Hospital in Zahedan in 2017. Convenience sampling was used to recruit the participants in accordance with the inclusion criteria. The subjects were randomly assigned to the control and intervention groups. Peer group training was then conducted for the intervention group for five days. KID-KINDL questionnaire to parent report was completed before intervention, immediately and two months after intervention for both intervention and control groups. Data were analyzed using descriptive and inferential tests at the significant level P-value $<0.05$.

Results: Before intervention, the mean score of total quality of life and its dimensions were not significantly different between the two groups $(P>0.05)$. Analysis of variance with repeated measures indicated that the mean scores of total quality of life and its dimensions in the intervention group were significantly increased over time $(P<0.001)$.

Conclusion: Using peer support program for mothers of children with ALL can improve the quality of life of children. Therefore, it is recommended to use this method alone or in combination with other methods to improve the quality of life of children with ALL.

Keywords: Support, Peer group, Mothers, Children, Acute Lymphoblastic Leukemia, Quality of life

Corresponding Information:

Azam Jamali, MSc in Pediatric Nursing, Faculty of Nursing and Midwifery, Zahedan University of Medical Sciences, Zahedan, Iran. Email: jamaliazam94@gmail.com

Copyright $(C)$ 2020, This is an original open-access article distributed under the terms of the Creative Commons Attribution-noncommercial 4.0 International License which permits copy and redistribution of the material just in noncommercial usages with proper citation.

How to Cite This Article:

Ghaljaei F, Fooladi S, Jamali A, Mahmoodi N, Zarei B. The Effect of Peer Support of Mothers of Children with Acute Lymphoblastic Leukemia on Quality of Life of Patients. Avicenna J Nurs Midwifery care. 2020; 28 (3) : 


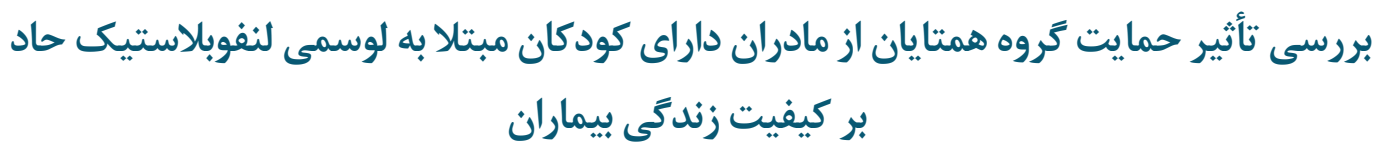

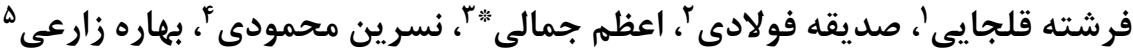

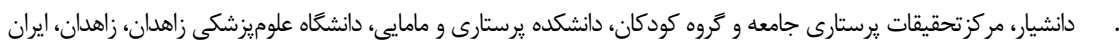

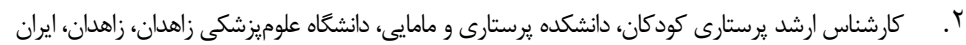

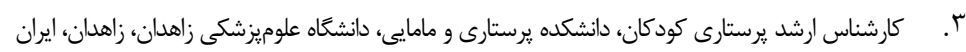

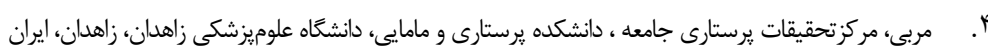

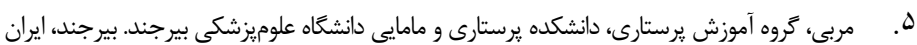

\begin{tabular}{|c|c|}
\hline جكيده & اطلاعات مقاله \\
\hline 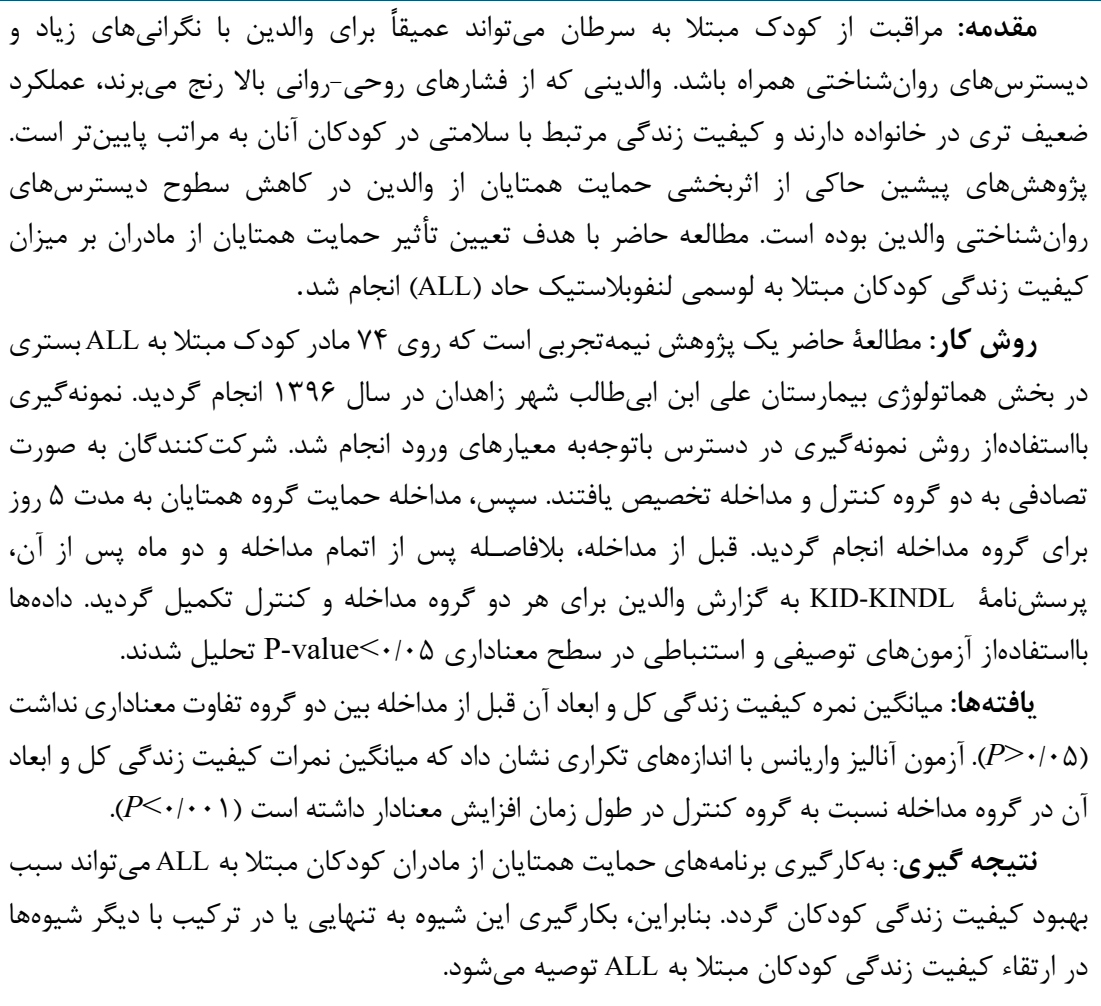 & 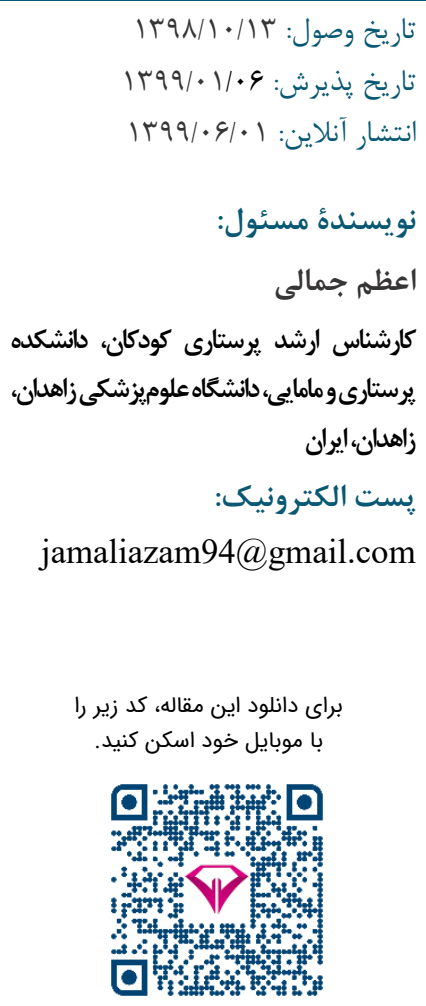 \\
\hline كا: حمايت، گروه همتايان، مادرا & \\
\hline
\end{tabular}

مقدمه

سرطان دومين عامل اصلى مرگ و مير در كودكان f | |-D ساله

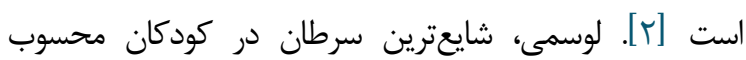
مىشود. بdطورى كه، سM درصد از كل بدخيمى هاى كودكان را به سهريه خود اختصاص مى دهد [ب]. لوسمى لنفوبلاستيك حاد 1 (ALL)
سرطان در كودكان و بزرگسالان ازجمله مرهمترين مشكلات سلامتى در سراسر جهان به شمار مىرود. تعداد مبتلايان به

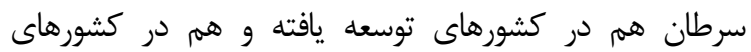
توسعهنيافته به تدريج در حال افزايش است [ا] ــ در ايران نيز

\footnotetext{
${ }^{1}$ Acute Lymphocytic Leukemia (ALL)
} 
از بدن، ذهن و روح كودك و همجنين حمايت از خانواده كودى

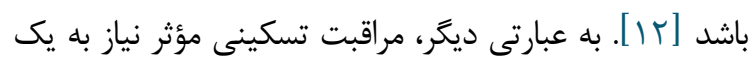

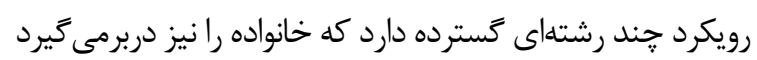

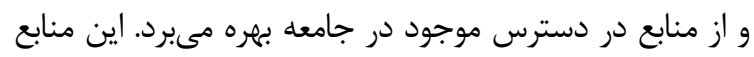
ممكن است شامل دوستان، شبكههاى اجتماعى، مكانهاى

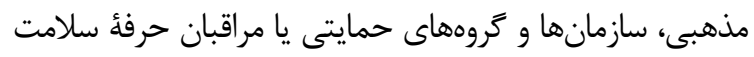

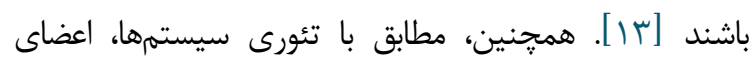

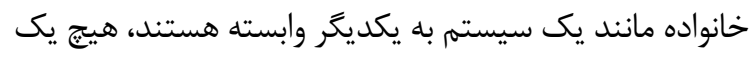

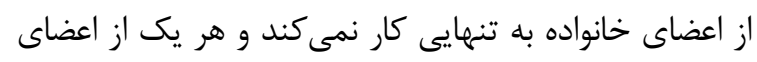

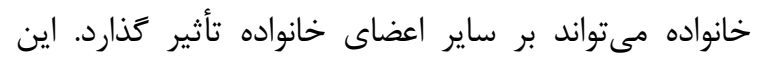

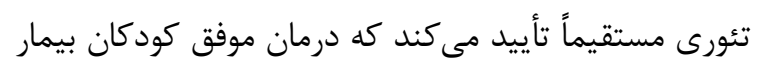

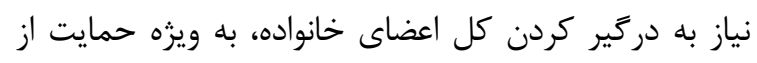

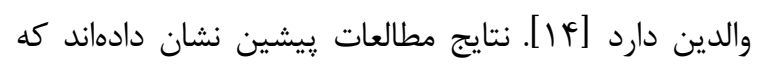

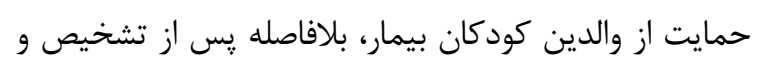

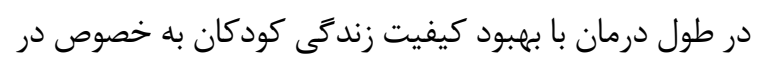
بعد عملكرد عاطفى آنان همراه بوده است [ـ [.1].

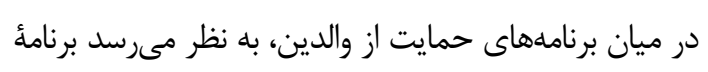

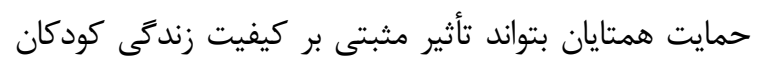
مبتلا به ALL ماشته باشد. در برنامةٔ حمايت همتايان افراد داراى تجربيات مشابه كرد

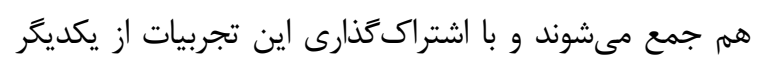

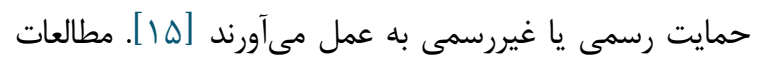
نشان دادهاند كه برنامههاى حمايت همتايان از والدين كودكان

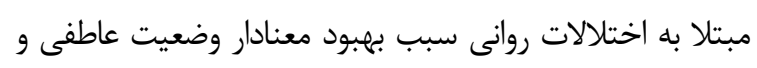

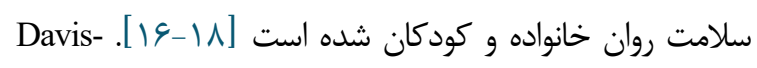
و و همكاران (Yroves

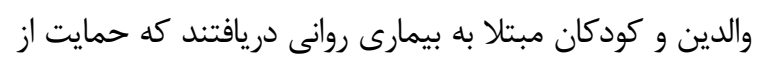

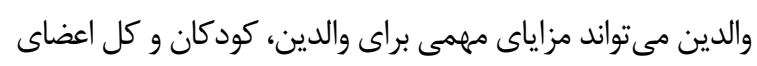

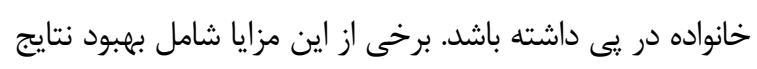

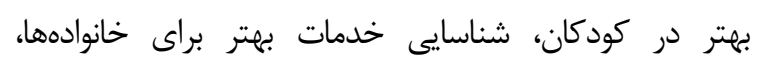

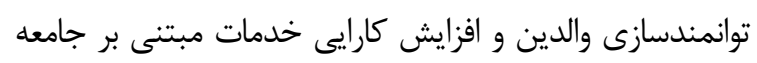

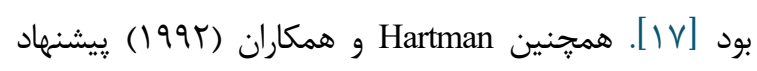
كردند كه حمايت همتايان از والدين يك وسيله مقابلهاى مؤثر

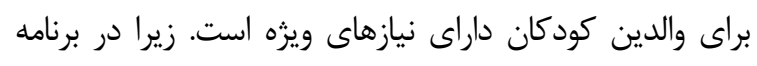

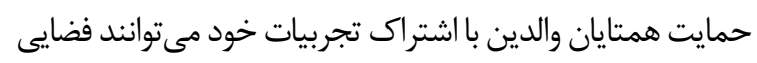

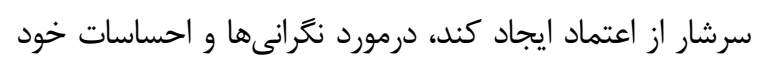

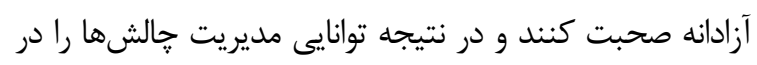

خود بهبود بخشند و اعتماد به نفس خود را زياد كنند [1 ا ]
شايعترين نوع لوسمى در كودكان است [4] . ييشرفتهاى حاصل

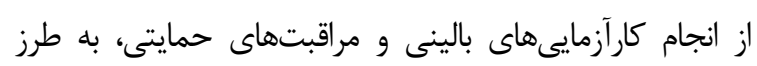

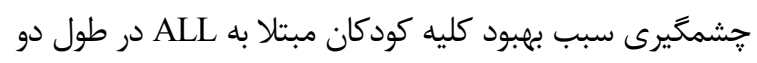

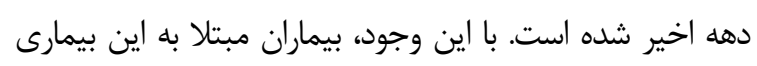
همجنان در معرض خطر مرى و و مير و يا ناخوشى هاى ناش ناشى از بيمارى و درمان هستند [هـ]. سرطان، تقريباً بر همأ حيطه ونهاى

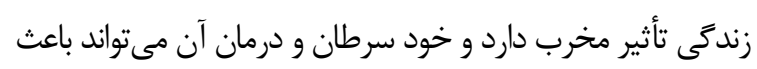

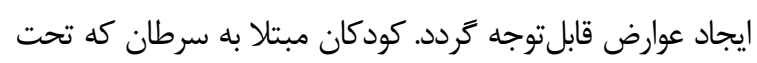

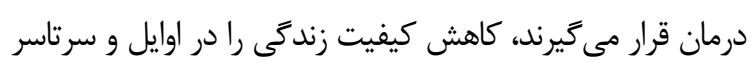

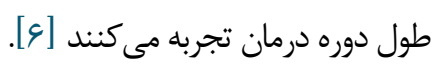

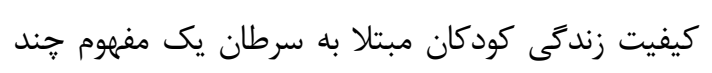

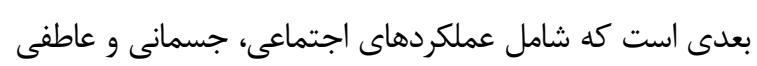

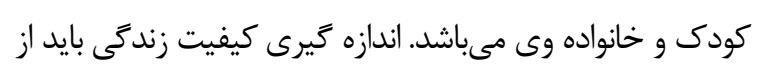

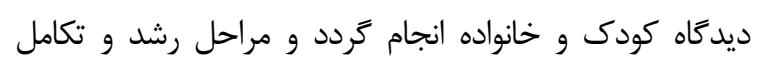

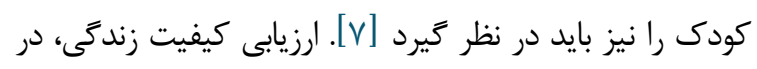
درمان كودكان مبتلا به سرطان نقش مهمى دارد. زير ايرا اطلاعات

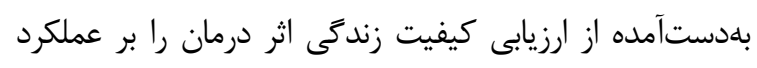

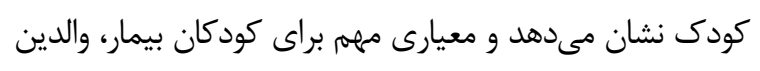

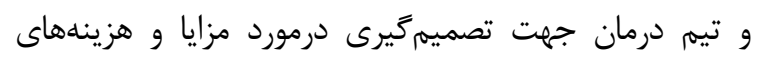

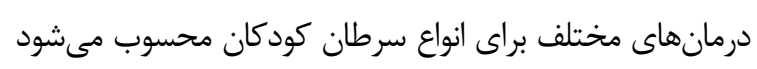

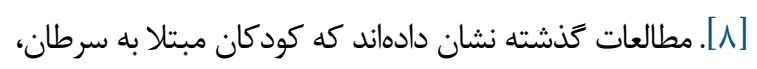
كاهش قابل توجه كيفيت زندكى را در مرحله حاد بيمارى تجربنه

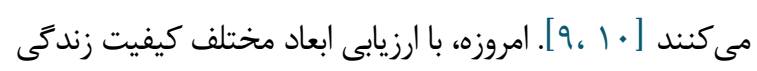

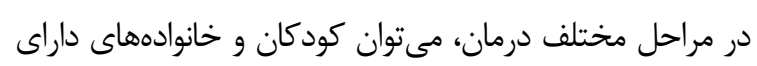

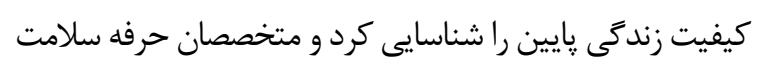

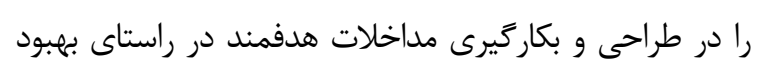

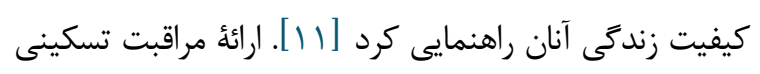

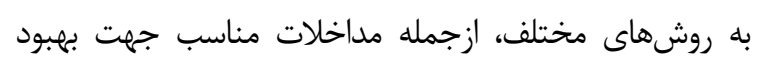
كيفيت زندگى محسوب مىشود.

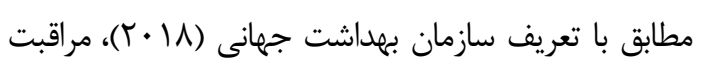
تسكينى نوعى رويكرد مراقبتى است كه سبب بهان بهبود كيفيت

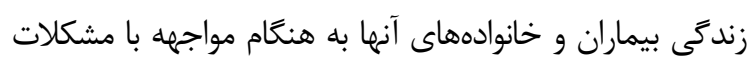

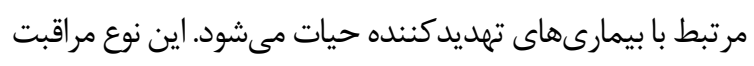
با هدف ييشخيرى و تسكين رنج از طريق شناسايى زود هنغام،

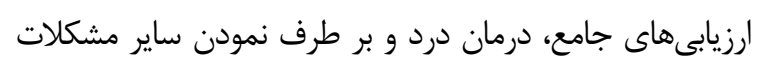

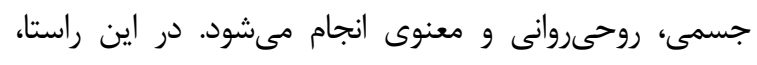

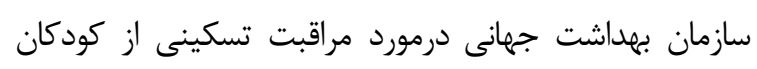
يادآور مىشود كه اين مراقبت تسكينى بايد شامل مراقبت كامل درد 
جسمانى تا حدى كه مانع از اجراى يزوهش نشود. معيارهاى خروج از مطالعه شامل عدم تمايل به ادامه مشاركت در درائ مداخله يا وقوع هر حادثهاى مانند فوت، مهاجرت و قطع درمان كودى كه باعث غيبت مادر بيش از دو جلسه در مداخله گَردد، بود.

يس از كرفتن كد اخلاق (Ir.zaums.REC.1396.115) براى طرح ييشنهادى مطالعه حاضر، يزوهشكر به محيط يزوهش مراجعه كرد. يزوهشكَ يس از معرفى خود به افراد داراى معيارهاى ورود به مطالعه و توضيح اهداف يزونه

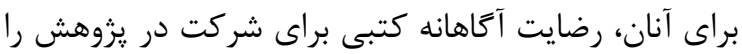
از ايشان كرفت و به آنان اطمينان داد كه اطلاعات بهدستآمده از آنان محرمانه باقى خواهد ماند.

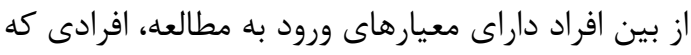
فرم رضايت آكاهانه را تكميل كرده بودند، وارد مطالعه شدند. در مرحلة بعد، اين شركت كنند

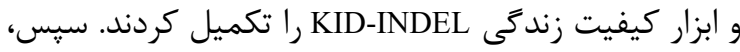
افراد بلهور تصادفى باستفادهاز روش بلوك كردن (بلوكهاى جهارتايى) با كمك نرمافزار تخصيص تصادفى به دو گروه كنترل و مداخله تقسيم شدند.

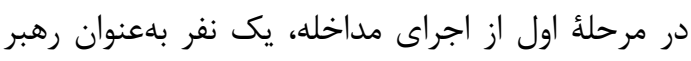

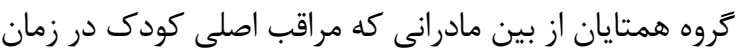

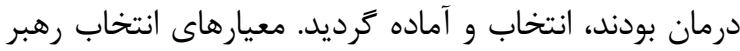
شامل مواردى مانند: 1 - تمايل و رضايت آكاهانه جهان مشاركت در اجراى مداخله، ؟-داشتن حداقل سطح تحصيلات دييلم، ץ-توانايى ارائه آموزش و برقرارى ارتباط با ديكران، عتسلط به زبان فارسى و بومى، ه- ساكن شهر زاهدان و و

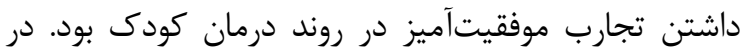
نهايت يك مادر با تحصيلات ليسانس كه كودى وى در آخرين

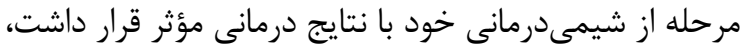
بلهنوان رهبر گروه همتايان انتخاب شد.

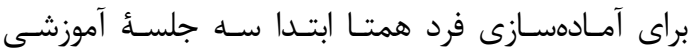

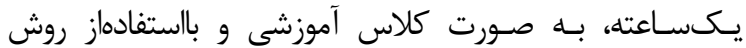
يرسـش و ياســخ و بــارش افــار بركــزار شد. در اين جلسات

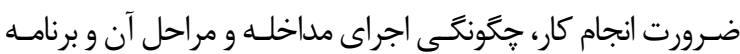

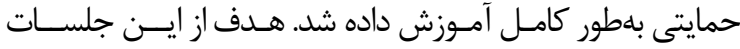

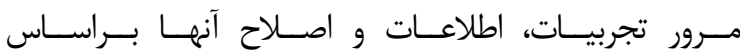

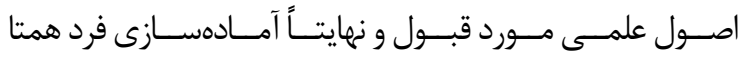
براى آمـوزش همتامحـور بود. وظيفأ فرد همتا كه رهبرى گروه
مراقبت از كودك مبتلا به سرطان مىتواند عميقاً براى والدين

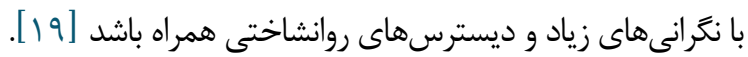

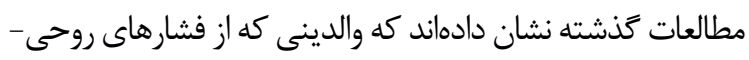
روانى بالا رنج مىبرند، عملكرد ضعيف ترى در خانواده دارند و كيفيت زندكى مرتبط با سلامتى در كودكان آنان به مراتب

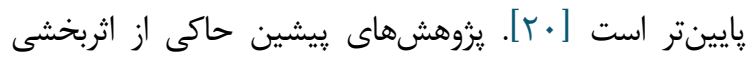

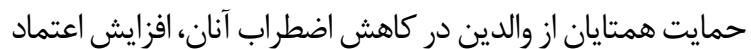
به نفس در مهارتهاى فرزنديرورى، بهبود توانايىهاى مديريت و تحمل استرس و كاهش سطوح ديسترسهاى روانشناختى

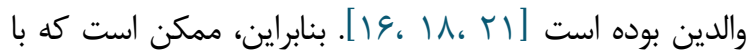
تغيير در وضعيت روانشناختى والدين بتوان كيفيت زندگى كودكان مبتلا به سرطان را تغيير داد. از آنجا كه مادران بيشتر از

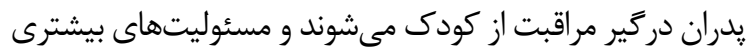

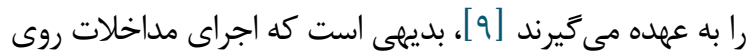
مادر خانواده مىتواند با نتايج بهتر روى كليه اعضاى خانواده همراه

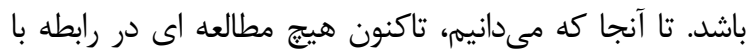
تعيين تأثير حمايت همتايان از مادران بر كيفيت زندگى كودكان آنان مبتلا به ALL در ايران انجام نكَرديده است، بنابراين، مطالعه

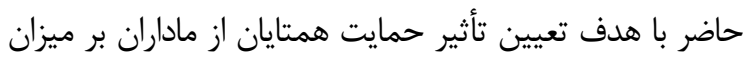
كيفيت زندگى كودكان مبتلا به ALL انجام شد.

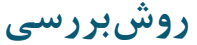

مطالعه حاضر يك مطالعهٔ نيمهتجربى به شيوه قبل و بعد

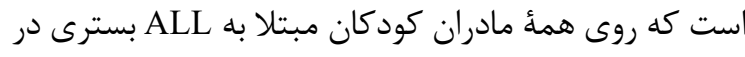

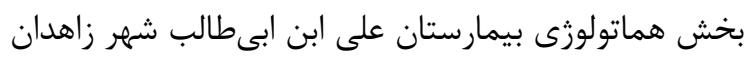

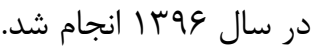
باتوجابه نيافتن مطالعه مشابه، حجم نمونه باستفادهاز

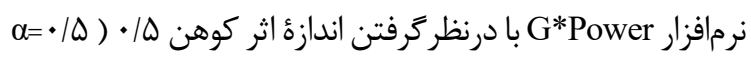

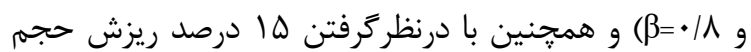
نمونه، •^ نفر تخمين زده شد (• أ نفر به ازاى هر كروه).

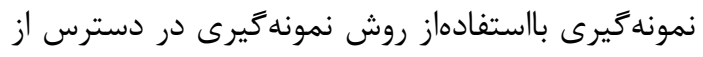
بين مادران كودكان مبتلا به سرطان خون باتوجهبه نونيه معيارهاى ورود انجام شد. معيارهاى ورود به مطالعه عبارت

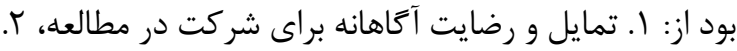

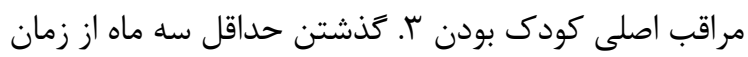
تشخيص بيمارى به تأييد تزشك متخصص، أ. نداشتن

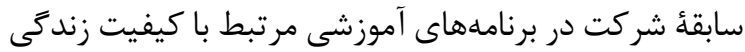

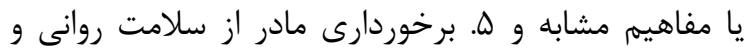


بررسى شدند. به گَونهاى كه شروع مداخله در افراد كروه

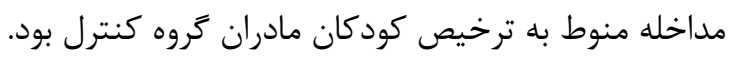

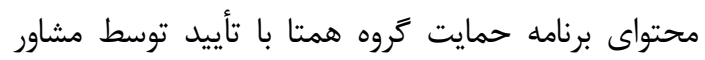

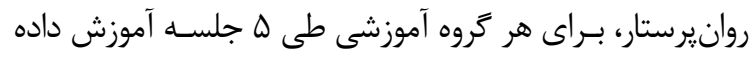

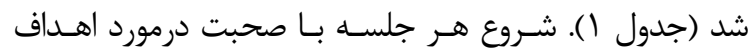

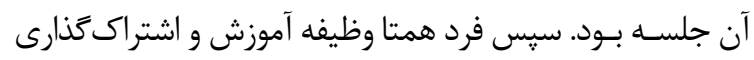

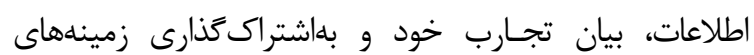
اجتماعى را انجام مىداد. در يايان هر جلسـه، فرد همتا موارد مطرح شده در كروه را جمعبنـدى كرد و بـه سـؤالات ياسخ داد.

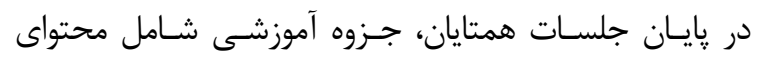

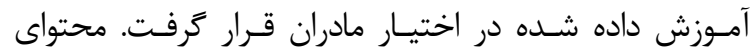

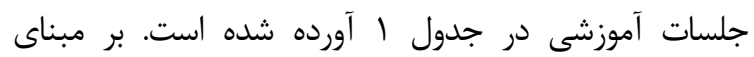

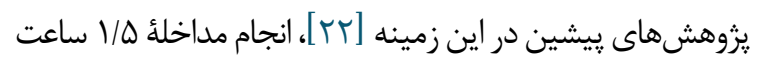

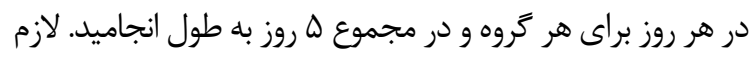
به ذكر است كه محل بركزارى جلسات، كلاس آموزشى موجود در بخش هماتولوزى بيمارستان على ابن ابى طالب (ع) بود و همأ جلسات در طول بسترى كودى در بيمارستان اجرا شد. بلافاصله

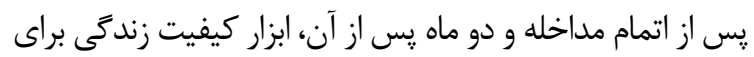
هر دو گروه مداخله و كنترل تكميل شد.
همتايان (شامل مادران كودكان مبتلا به ALL شركت كننده در

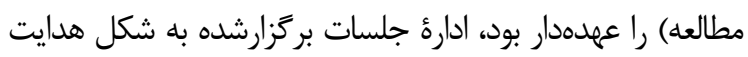

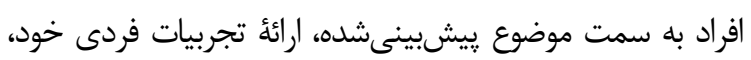
تشويق افراد جهت شركت در مباحث و در نهايت جمعبندى

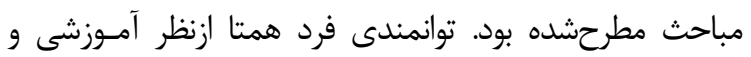

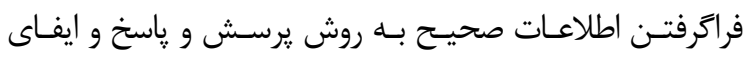
نقش مورد ارزيابى قرار كرفت.

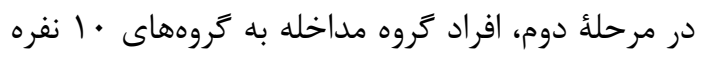
تقسيم شدند. سيس از فرد همتا درخواست شد تا در يك

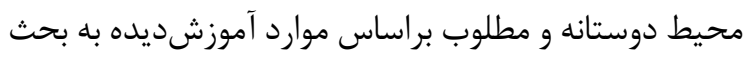
و هدايت تروه بيردازد. يزوهشكران وظيفه تهيه محتوا و ودان

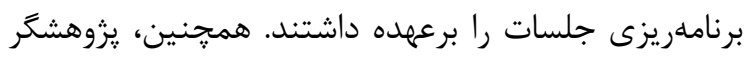
اصلى (نويسنده مسئول) بهعنوان ناظر در كليه جلسات

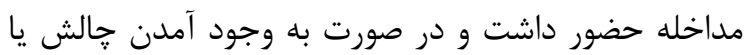
مشكل رهبر كروه را يارى مىنمود.

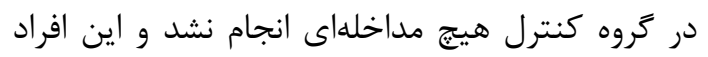

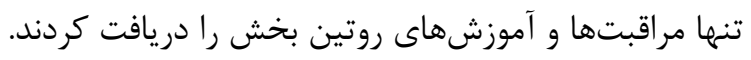

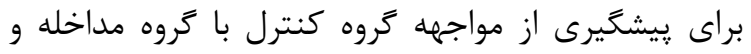
كاهش احتمال تبادل اطلاعات، ابتدا كروه كنترل انتخاب و و كرو

جدول ا. محتواى برنامه آموزش همتايان

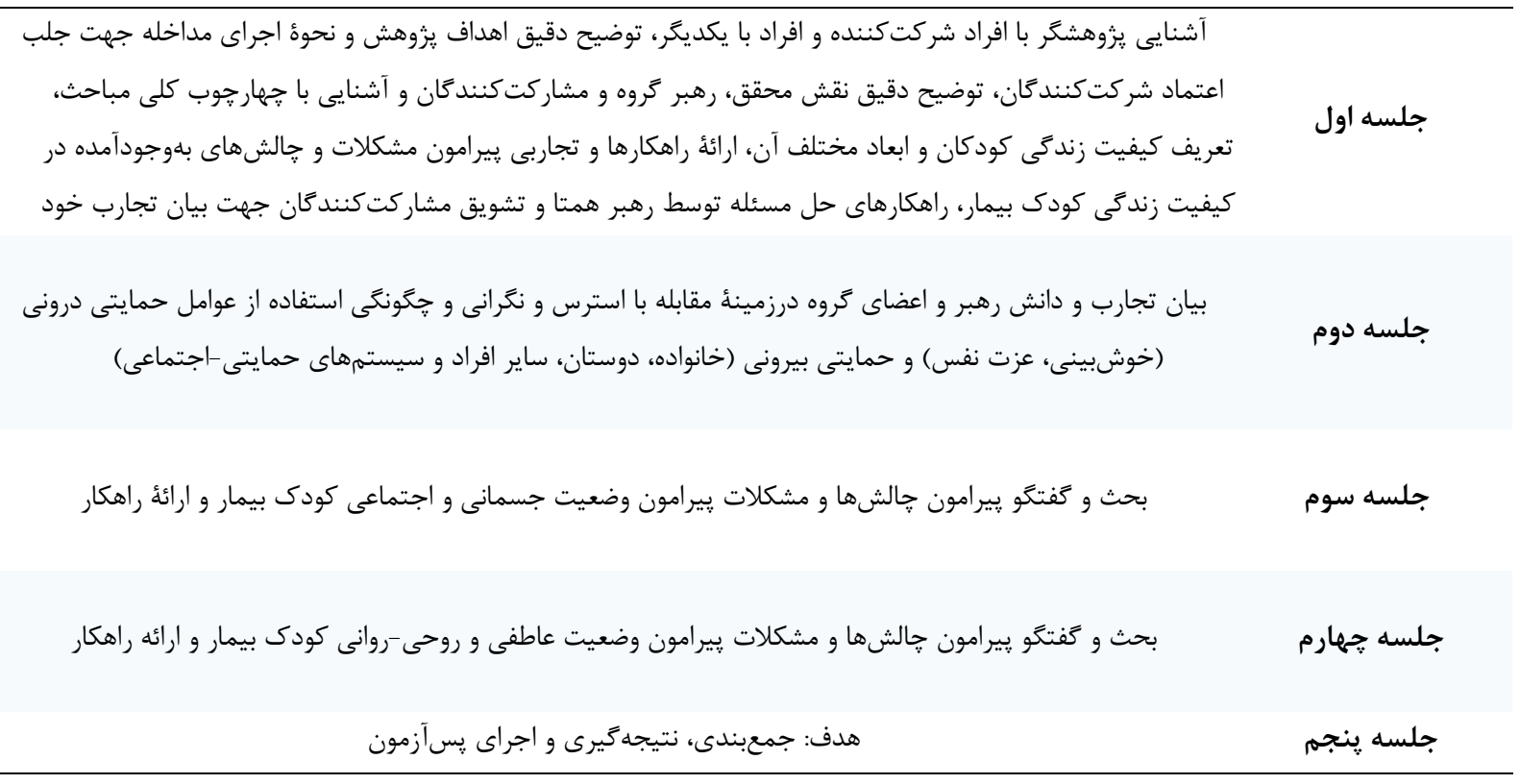

تحصيلات مادر و يرسشنامه KID-KINDL به گزارش

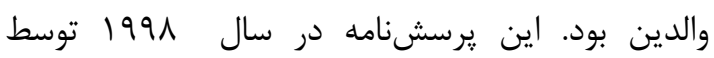

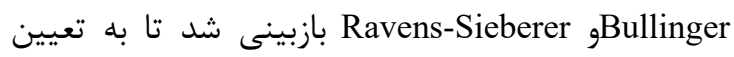

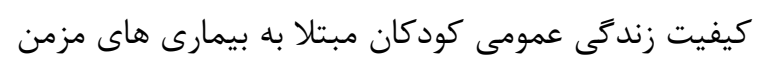

ابزارهاى جمعآورى اطلاعات شامل يرسشنامه اطلاعات جمعيتشناختى مشتمل بر سؤالاتى در رابطه با سن مادر،

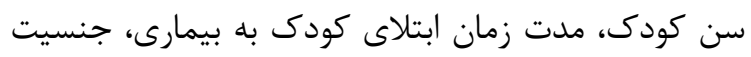

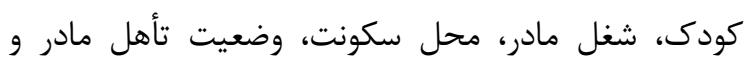


مانند كاىدو (تست دقيق فيشر)، تىمستقل و تحليل واريانس با اندازههاى تكرارى استفاده شد.

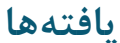

يزوزهش حاضر با تعداد VF مادر شركت كننده در مطالعه به اتمام رسيد. از اين تعداد شركت كنندكان عَ نفر به كروه مداخله و

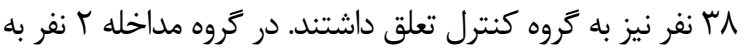
علت انتقال كودكانشان به بيمارستانهاى مجهزتر در شهرى ديخر از ادامئ شركت در مداخله انصراف دادند و بقيئ مادران بهدليل غيبت بيش از Y جلسه در كلاسهاى آموزش همتاز مطالعه كنار كذاشته شدند. در كروه كنترل نيز r نفر به دليل عدم شركت در جلسات بيش از دو جلسه از مطالعه كنار كذاشته شدند. ميانكين سنى مادران برحسب سال در كروه مداخله

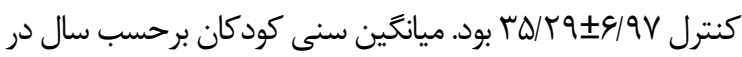
كروه مداخله VV همجنين ميانگين طول مدت بيمارى كودى برحسب ماه در كروه

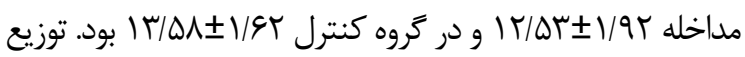
فراوانى ساير متغيرهاى جمعيتشناختى بر حسب كروه در جدول

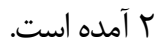
براساس نتايج جدول r توزيع متغيرهاى دموكرافيك در دو كروه مداخله و كنترل همگن بود و تفاوت معنادارى نداشت

$$
(P>\cdot / \cdot \Delta)
$$

ازجمله سرطان بيردازد [بr]. اين يرسشنامه داراى ץF كَويه است كه كيفيت زندگى كودى به كزارش والدين را در ابعاد جسمى، عاطفى، روانشناختى (اعتماد به نفس)، عملكرد خانوادگى، اجتماعى و مدرسه بررسى ميى كند. علاوهبر آن آن داراى V سؤال مربوط به بسترى شدن كودى بيمار نيز

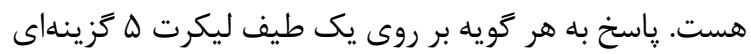

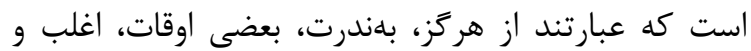

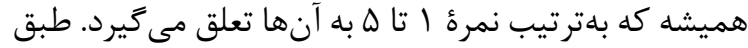
دستورالعمل ارجاعى تدوينكر نمرهدهى برخى از موارد به

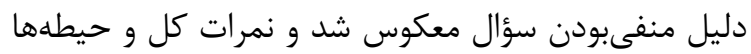
محاسبه گرديد و در نهايت به صفر تا صد نيز تبديل شد. روايى يرسشنامه فارسى در مطالعة لvalizadeh و همكاران

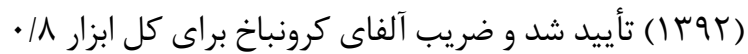

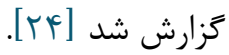
دادهها باستفادهاز آمار توصيفى و استنباطى در نرمافزار

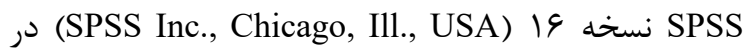
سطح معنادارى Q•/P-value تجزيه و تحليل شدند. از

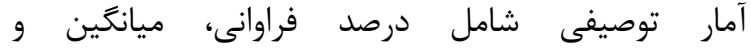

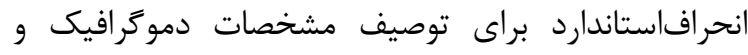
توصيف متغيرهاى اصلى مطالعه استفاده شد. سيس،

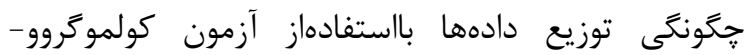
اسميرنوف بررسى شد. در ادامه از آزمونهاى استنباطى آلى آدها

جدول r. بررسى توزيع فراوانى متغيرهاى دموكَ افيك در گروههاى مورد مطالعه

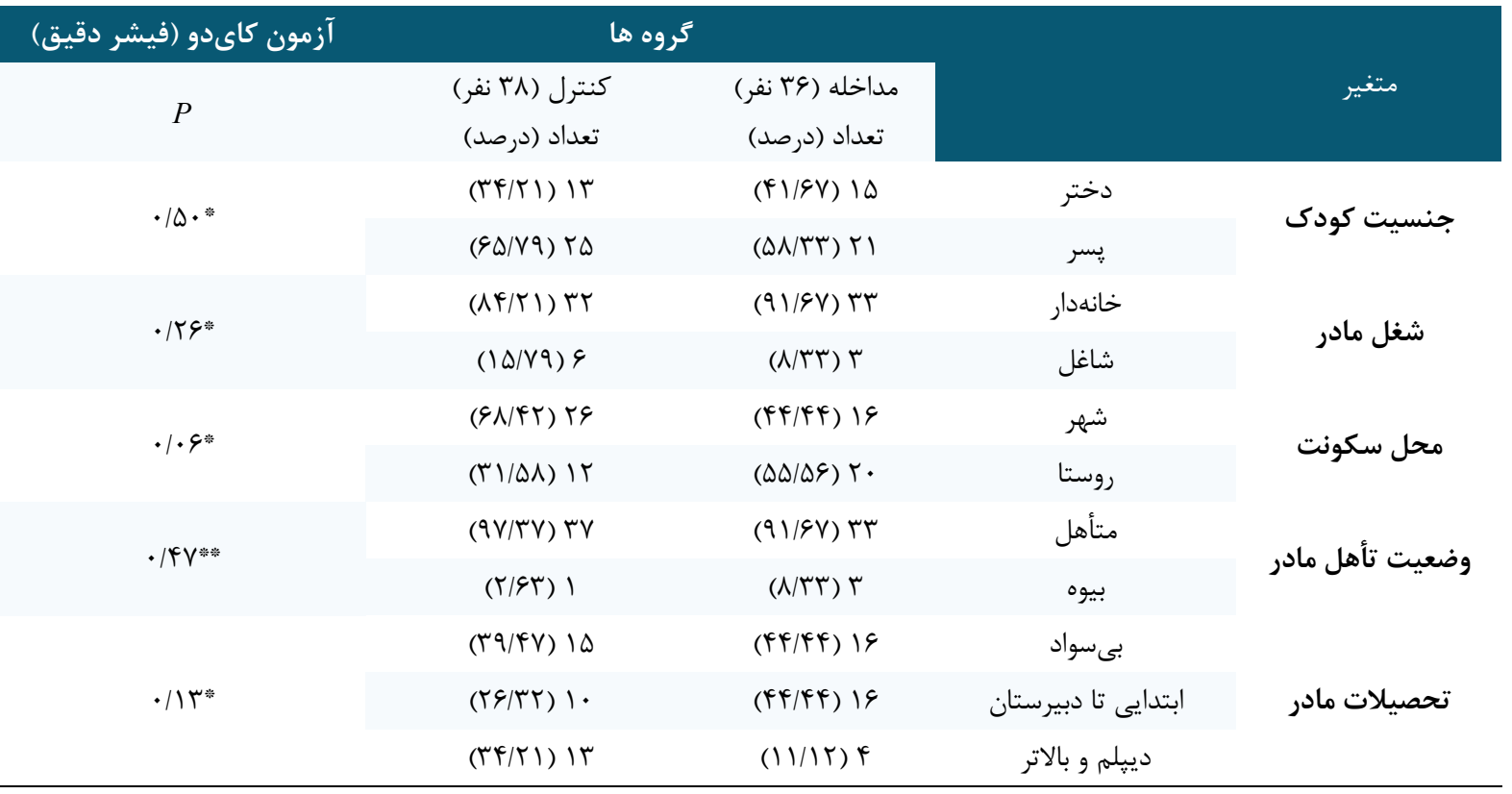

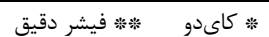


فرشته قلجايى و همكاران IVV

متغيرهاى تابآورى و ابعاد آن در دو گروه مداخله و كنترل از توزيع نتايج حاصل از آزمون كولموگروف-سميرنوف نشان داد كه

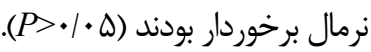

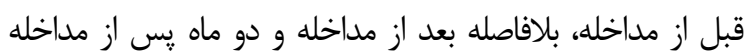

جدول لr. مقايسه ميانگين نمرات كيفيت زندگى كل و ابعاد آن در دو گروه مداخله و كنترل در زمان قبل از مداخله

\begin{tabular}{|c|c|c|c|}
\hline$P$ & ميانَين 土 انحراف معيار & كروه & متغير \\
\hline \multirow{2}{*}{ r } & $G \cdot|f| \pm \mid g / V F$ & مداخله & \multirow{2}{*}{ جسمانى } \\
\hline & $\Delta \cdot / \cdot \Delta \pm r \cdot|r|$ & كنترل & \\
\hline \multirow{2}{*}{$\cdot / 19$} & $\varepsilon \Delta / q \vee \pm 1 Q / Y q$ & مداخله & \multirow{2}{*}{ عاطفى } \\
\hline & $\varepsilon r / r G \pm \mid r / \cdot \Lambda$ & كنترل & \\
\hline \multirow{2}{*}{. } & $\varepsilon \Delta / T V \pm I N / 9 \varphi$ & مداخله & \multirow{2}{*}{ روانشناختى } \\
\hline & s)/FY $\pm r r / \Lambda$. & كنترل & \\
\hline \multirow{2}{*}{. 194} & $\Delta F / / \varepsilon \pm q / \wedge q$ & مداخله & \multirow{2}{*}{ خانوادكى } \\
\hline & $\Delta r / q F \pm 1 r / r G$ & كنترل & \\
\hline \multirow{2}{*}{$\cdot 190$} & $V \cdot|\Lambda r \pm| \Delta / \cdot r$ & مداخله & \multirow{2}{*}{ اجتماعى } \\
\hline & $99 / 7| \pm| 0 / 9 \mid$ & كنترل & \\
\hline \multirow{2}{*}{ - IAr } & $G T / \Delta \cdot \pm q / r V$ & مداخله & \multirow{2}{*}{ بعد مدرسه } \\
\hline & $G r / 9 V \pm 9 / \wedge r$ & كنترل & \\
\hline \multirow{2}{*}{$\cdot 190$} & 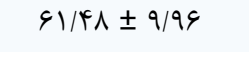 & مداخله & \multirow{2}{*}{ بسترى بس } \\
\hline & $G Y / \Delta F \pm 1 \cdot / T F$ & كنترل & \\
\hline \multirow{2}{*}{$\cdot / \Gamma \Lambda$} & $G T / \wedge D \pm q / 4 G$ & مداخله & \multirow{2}{*}{ كيفيت زندَى كل } \\
\hline & $q 1 / \cdots q \pm \Lambda / q \Delta$ & كنترل & \\
\hline
\end{tabular}

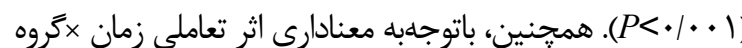
براى نمرءٔ كل كيفيت زندگى و ابعاد آن نتيجه مىشود كه اين تغييرات معنادار به گروه وابسته است و باتوجهبه ميانگين نمرات

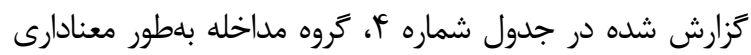
ميانگين نمرات بالاترى را نسبت به گروه كنترل زَارش كرده است

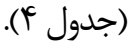

مطابق جدول ب، نتايج آزمون تىمستقل نشان داد كه ميانخين

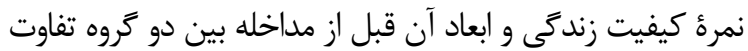
معنادارى نداشته است (ه •/ • (P>). مطابق با جدول عا، نتايج آزمون تحليلواريانس با اندازههاى

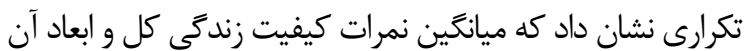
در طول زمان (منبع زمان) تغييرات معنادارى داشته است دمرئ

جدول F. مقايسه ميانگين نمره كيفيت زندكى كل و ابعاد آن در كودكان مبتلا به لوسمى، قبل، بلافاصله و دو ماه بعد از مداخله در دو كروه مداخله و كنترل

\begin{tabular}{|c|c|c|c|c|c|c|c|}
\hline$P$ & $\mathrm{~F}$ & منبع & دو ماه بعد از & بلافاصله بعد از & قبل از مداخله & كروه & متغير \\
\hline$\cdot 1 \cdot 1$ & $9 / 9$. & تروه & \multirow{2}{*}{$V V / D \cdot \pm I Q / V F$} & \multirow{2}{*}{$99 / 11 \pm 1 r / 1 r$} & \multirow{2}{*}{$G \cdot|F| \pm \mid \varepsilon / V F$} & \multirow{2}{*}{ مداخله } & \multirow{3}{*}{ جسمانى } \\
\hline$<\cdot 1 \cdot \cdot 1$ & $r \cdot / 4 \varphi$ & زمان & & & & & \\
\hline $.1 \cdot r$ & $r / 9 \Lambda$ & تروه ×زمان & $q F / \cdot V \pm \mid F / T V$ & $\Delta \varepsilon / V| \pm r \cdot| \Lambda \varepsilon$ & $\Delta \cdot|\cdot \Delta \pm r \cdot| r \mid$ & كنترل & \\
\hline$\cdot 1 \cdot 1$ & s/VG & تروه & \multirow{2}{*}{$V V / T G \pm 1 \cdot / D T$} & \multirow{2}{*}{ GN/Tr $\pm I T / \Delta K$} & \multirow{2}{*}{$\varepsilon \Delta / q \vee \pm 1 \Delta / r q$} & \multirow{2}{*}{ مداخله } & \multirow{3}{*}{ عاطفى } \\
\hline$<\cdot 1 \cdot \cdot 1$ & $19 / \mathrm{VV}$ & زمان & & & & & \\
\hline$<\cdot 1 \cdot \cdot 1$ & $f|q|$ & گروه ×زمان & $G 9 / \cdot \Delta \pm \mid r / V F$ & $G r / F| \pm| r / q r$ & $G K / r G \pm \mid F / \cdot \Lambda$ & كنترل & \\
\hline - kt & $f / \mu$. & تروه & \multirow{2}{*}{$11 / 9 F \pm 1 \cdot 10 V$} & \multirow{2}{*}{$\varepsilon \Lambda / \cdot \Delta \pm \mid \varepsilon / 4 \Lambda$} & \multirow{2}{*}{$9 \Delta / r V \pm 1 N / 99$} & \multirow{2}{*}{ مداخله } & \multirow{3}{*}{ روانشناختى } \\
\hline$<\cdot / \cdot \cdot 1$ & $r F / 91$ & زمان & & & & & \\
\hline$<\cdot 1 \cdot \cdot 1$ & $\mid r / \cdot 1$ & گروه ×زمان & $G G / F F \pm 19 / \Delta G$ & $91 / 9 \Delta \pm r r / 9 r$ & $G / / F F \pm T r / \Lambda$. & كنترل & \\
\hline
\end{tabular}

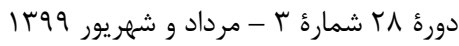




\begin{tabular}{|c|c|c|c|c|c|c|c|}
\hline$P$ & $\mathrm{~F}$ & منبع & دو ماخله بعد از & بلافاصله بعد از & قبل از مداخله & كروه & متغير \\
\hline$\cdot|\pi|$ & $1 / \cdot r$ & كروه & \multirow{2}{*}{$\Lambda \Delta / q \vee \pm 1 \cdot / / 9$} & \multirow{2}{*}{$V \Psi / 91 \pm 11 / \Delta}$. & \multirow{2}{*}{$\Delta F / / \& \pm 9 / \wedge q$} & \multirow{2}{*}{ مداخله } & \multirow{3}{*}{ خانوادَى } \\
\hline$<\cdot / \cdot \cdot \cdot 1$ & $r F q / . q$ & زمان & & & & & \\
\hline$<\cdot \mid \cdot \cdot 1$ & $9 / 9$. & كروه ×زمان & $V V / V G \pm I Y / \Delta \Delta$ & $V \psi / \cdot V \pm 18 / 9 r$ & $\Delta r / q Y \pm 1 r / T G$ & كنترل & \\
\hline .119 & $r / \cdot 1$ & كروه & \multirow{2}{*}{$1 \cdot / 9 \vee \pm 9 / 99$} & \multirow{2}{*}{$V r / \cdot \Delta \pm \mid r / \cdot \Lambda$} & \multirow{2}{*}{$V \cdot|\lambda r \pm| \Delta / \cdot r$} & \multirow{2}{*}{ مداخله } & \multirow{3}{*}{ اجتماعى } \\
\hline$<\cdot \mid \cdot \cdot 1$ & $r$ r/gV & زمان & & & & & \\
\hline$<\cdot / \cdot \cdot 1$ & $r / 9 \Delta$ & كروه ×زمان & $V Y / \wedge q \pm \mid F / V V$ & $99 / V r \pm 19 / T V$ & $89 / \pi| \pm| \Delta / 9 \mid$ & كنترل & \\
\hline 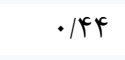 & $\cdot 1 \cdot 1$ & تروه & \multirow{2}{*}{$G N / F V \pm V / \cdot D$} & \multirow{2}{*}{ GT/QG $\pm 9 / \Delta r$} & \multirow{2}{*}{$q \Gamma / \omega \cdot \pm q / \Gamma V$} & \multirow{2}{*}{ مداخله } & \multirow{3}{*}{ مدرسه } \\
\hline$<\cdot|\cdot \cdot|$ & $N / F V$ & زمان & & & & & \\
\hline$<\cdot / \cdot \cdot 1$ & V/VF & كروه ×زمان & $q \pi / l \cdot \pm N / r V$ & $9 T / 99 \pm 1 \cdot / 4 T$ & $9 r / 9 V \pm 9 / \wedge r$ & كنترل & \\
\hline$\cdot \pi \Delta$ & $\cdot / \Lambda \Lambda$ & كروه & \multirow{2}{*}{$V 1 / 4 \wedge \pm 1 . / \cdot r$} & \multirow{2}{*}{$91 / \wedge \Delta \pm 9 / 9 \Gamma$} & \multirow{2}{*}{$91 / \uparrow \wedge \pm 9 / 99$} & \multirow{2}{*}{ مداخله } & \multirow{3}{*}{ بسترى } \\
\hline$<\cdot|\cdot \cdot|$ & $|N| \cdot \Lambda$ & زمان & & & & & \\
\hline$<\cdot|\cdot \cdot|$ & $1 . / 94$ & كروه ×زمان & $G / / V V \pm \mid r / r \Lambda$ & $G K / \Delta F \pm 1 \cdot / I V$ & $G K / \Delta F \pm 1 \cdot / T F$ & كنترل & \\
\hline$<\cdot|\cdot \cdot|$ & N/AV & كروه & \multirow{2}{*}{$V V / \Gamma \Delta \pm \Delta / r \Lambda$} & \multirow{2}{*}{$q V / T F \pm V / q V$} & \multirow{2}{*}{$G 广 / \wedge \Delta \pm 9 / 4 \varphi$} & \multirow{2}{*}{ مداخله } & \multirow{3}{*}{ كيفيت زندىى } \\
\hline$<\cdot|\cdot \cdot|$ & |rr/gd & زمان & & & & & \\
\hline$<\cdot / \cdot \cdot 1$ & $r$ rMF & كروه ×زمان & $q V / 11 \pm V / F T$ & 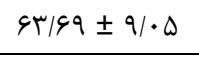 & $91 / . .9 \pm 1 / 90$ & كنترل & \\
\hline
\end{tabular}

والدين شركت كننده در برنامهٔ حمايت همتا، تغييرات مثبتى را كار در سلامت روانشناختى خود كزارش كردند كه بلنوبئ خود

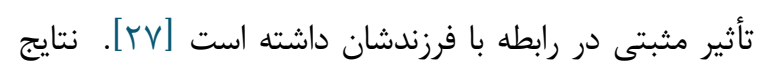

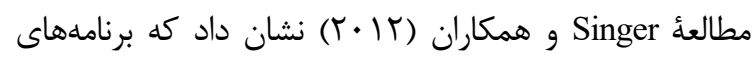

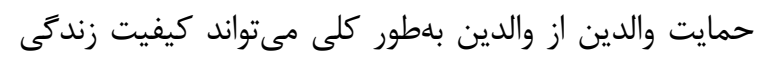

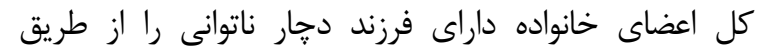

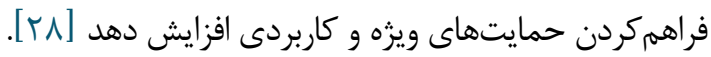

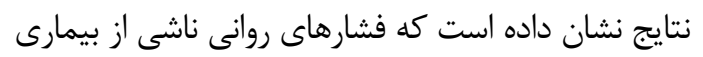

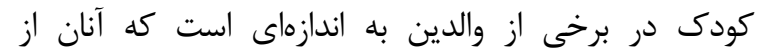

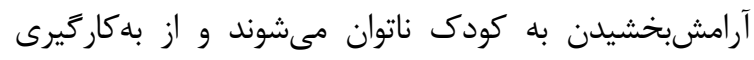

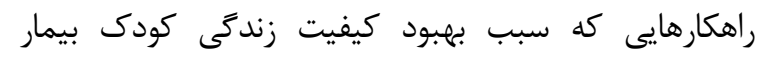

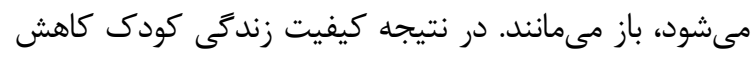

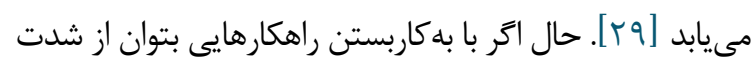
فشارهاى روانى بر والدين كاست، مىتوان انتظار داشت كابن كه

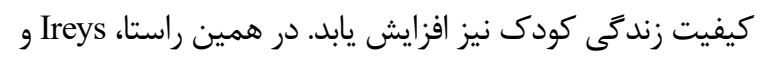

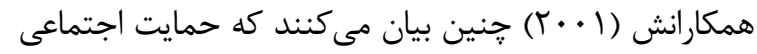

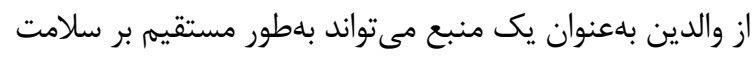

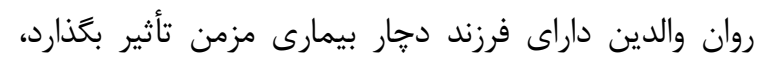

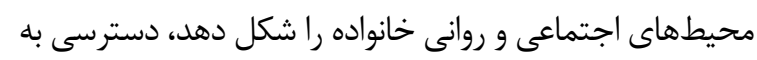

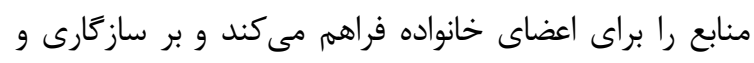

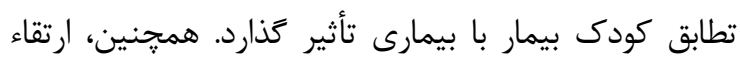

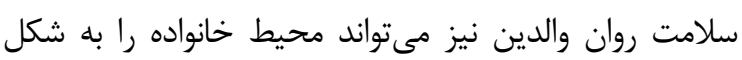

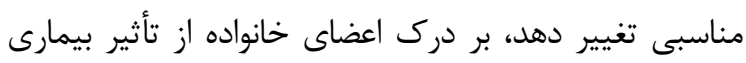

مطالعة حاضر با هدف تعيين تأثير حمايت همتايان از مادران

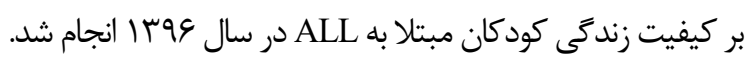

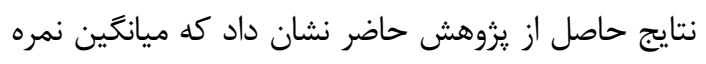

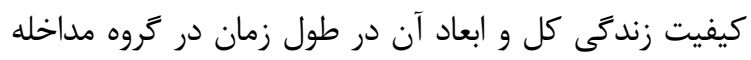

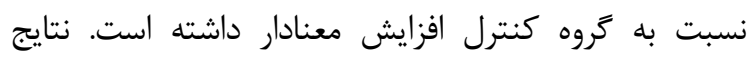

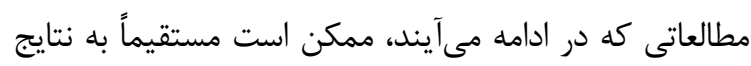
يزوهش كنونى مرتبط نباشد، اما در راستاى تأييد يافتهها مى متواند حائز اهميت باشند.

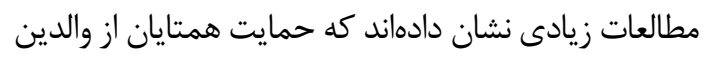

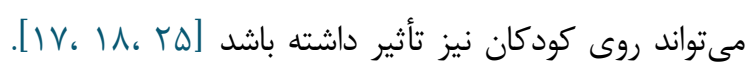

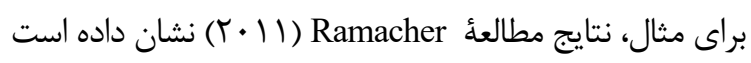

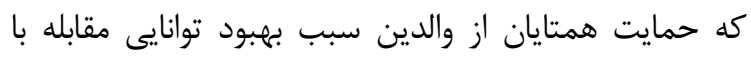

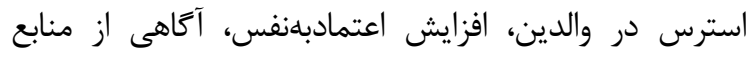

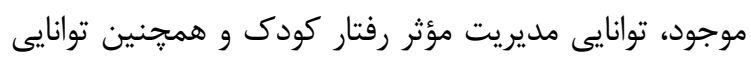

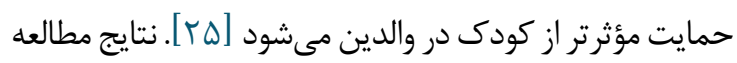
Davis-Groves كه حمايت همتايان از والدين به سبب مزايايى كه براي والدين

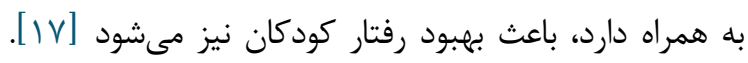

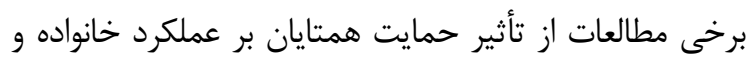

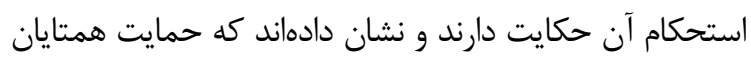

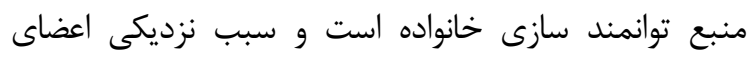

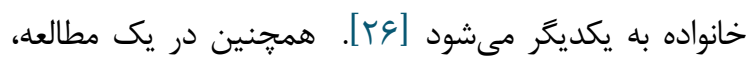


متغيرهاى روانشناختى مانند بهزيستى ذهنى كودكان مبتلا به بيمارىهاى مزمن بيردازند.

$$
\text { نتيجه گيرى }
$$

بهره گيرى از برنامههاى حمايت همتايان از مادران

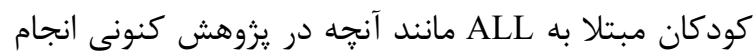
شد، مىتواند سبب بهبود كيفيت زندگى كودكان شود. بنابراين، استفاده از اين برنامهٔ حمايتى بهتنهايى يا در تركيب

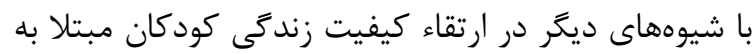
ALL

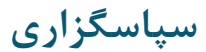

مقاله حاضر بخشى از زياياننامهُ دانشجويى مصوب دانشعاه علوميزشكى زاهدان با كد سع NF است. بدين وسيله مراتب قدردانى و تشكر خودمان را از حمايت تمامى عزيزانى كه به هرنحوى ما را در انجام اين طرح يارى كردند و مادران شر كت كننده در يزوهش اعلام مى كنيم.

$$
\text { تعارض در منافع }
$$

بين نويسندكان هيج گونه تعارضى در منافع وجود ندارد

$$
\text { منابع مالى }
$$

منابع مالى اين مطالعه توسط نويسندكان تامين شده است.

\section{References}

1. American Cancer Society. Cancer facts and figures [Internet]. Atlanta, USA: Author; 2015 [cited 2015 Oct 15]. Available from: http://www.cancer.org/acs/ groups/content/@editorial/documents/document/acsp c-044552.pdf

2. Mojen LK, Rassouli M, Eshghi P, Zendedel K, Sari AA, Karimooi MH, Tahmasebi M, Farahani AS. Pediatric Palliative Care in Iran: Applying Regionalization of Health Care Systems. Asia Pacific J Cancer Prev. 2018; 19(5):1303.

3. Pesola F, Ferlay J, Sasieni P. Cancer incidence in English children, adolescents and young people: past trends and projections to 2030. Br J Cancer. 2017; 117(12):1865. [DOI:10.1038/bjc.2017.341] [PMID] [PMCID]

4. Ward E, DeSantis C, Robbins A, Kohler B, Ahmedin J. Childhood and adolescent cancer statistics. 2014. CA Cancer J Clin. 2014; 64(2):83-103. [DOI:10.3322/caac.21219] [PMID]
مزمن بر خانواده تأثير بخذارد و بلنوبة خود سبب سازكارى

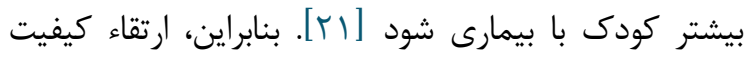

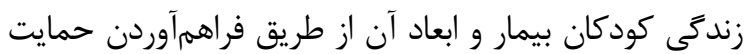
اجتماعى از والدين مانند حمايت همتايان با عنايت به فوايد بىشمارى كه در مطالعات كذشته نشان داده شده است، قابل توجيه است. استفاده از طرح كارآزمايى تصادفىشده، ميزان ريزش كم نمونه و بهكارگيرى ابزار معتبر و يايا در مطالعه براى اندازهزيرى كيفيت زندگى كودكان از قوتهاى مطالعه محسوب مىشوند. در عين حال، مطالعه داراى محدوديتهايى است،

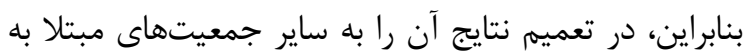
سرطان خون بايد جانب احتياط رعايت شود. نخست اينكه انتخاب نمونههاى يزوهش تنها از يك مركز درمانى صورت

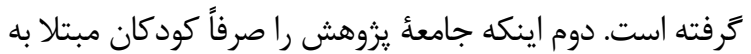

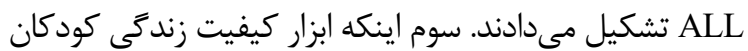
صرفاً توسط مادران كودكان مبتلا به ALL تكميل شده است و ازآنجاكه مطالعات كذشته حاكى از تأثير حمايت همتايان در مرد

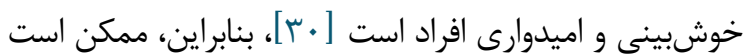
نمرء كيفيت زندگى كودكان تحت تأثير احساسات پيديدآمده در

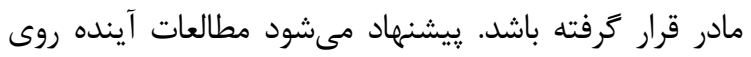

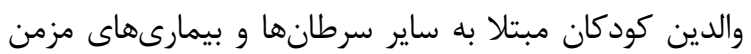
انجام شود و ابزار كيفيت زندگى از ديدگاه خود كودى نئ نيز

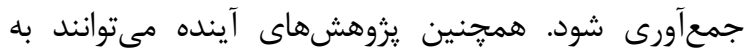
بررسى تأثير حمايت همتايان از والدين بر سبك زندى تهى و ساير

5. Hunger SP, Lu X, Devidas M, Devidas M, Camitta BM, Gaynon PS, et al. Improved survival for children and adolescents with acute lymphoblastic leukemia between 1990 and 2005: a report from the Children's Oncology Group. J Clin Oncol. 2012; 30:1663-9. [DOI:10.1200/JCO.2011.37.8018] [PMID] [PMCID]

6. Yariş N, Yavuz MN, Yavuz AA, Ökten A. Assessment of quality of life in pediatric cancer patients at diagnosis and during therapy. Turk J Cancer. 2001; 31(4):139-49.

7. Bradlyn AS, Ritchey AK, Harris CV, Moore IM, O'Brien RT, Parsons SK, et al. Quality of life research in pediatric oncology. Cancer. 1996; 78(6):1330-2. https://doi.org/10.1002/(SICI)10970142(19960915)78:6<1333::AID-

CNCR24>3.0.CO;2-0 [DOI:10.1002/(SICI) $1097-$ 0142(19960915)78:63.0.CO;2-0]

8. Mounir G M, Abolfotouh M A. Assessment of healthrelated quality of life among school children with cancer in Alexandria. J Egypt Public Health Assoc. 2007; 82(3,4):219-38. 
9. Eiser C, Eiser JR, Stride CB. Quality of life in children newly diagnosed with cancer and their mothers. Health Qual Life Outcom. 2005; 3: 29 [DOI:10.1186/14777525-3-29] [PMID] [PMCID]

10. Matziou V, Perdikaris P, Galanis P, Dousis E, Tzoumakas K. Evaluating de-pression in a sample of children and adolescents with cancer in Greece. Int Nurs Rev. 2008; 55:314-9. [DOI:10.1111/j.14667657.2008.00606.x] [PMID]

11. Sung L, Klaassen R, Dix D, Pritchard S, Yanofsky R, Dzolganovski $\mathrm{B}$, et al. Identification of pediatric cancer patients with poor quality of life. Br J Cancer. 2009; 100:82-8. [DOI:10.1038/sj.bjc.6604826] [PMID] [PMCID]

12. WHO. Palliative Care. 2018. Availbale online at: http://www.who.int/news-room/factsheets/detail/palliative-care

13. Gielen AC, McDonnell KA, Wu AW, O'Campo P, Faden R. Quality of life among women living with HIV: the importance violence, social support, and selfcare behaviors. Soc Sci Med. 2001; 52(2):315-22. [DOI:10.1016/S0277-9536(00)00135-0]

14. DeGenova MK, Rice FP. Intimate relationships, marriages, \& families. 5th ed. Boston, MA: McGraw Hill. 2002.

15. Polinsky ML, Pion-Berlin L, Williams S, Long T, Wolf AM. Preventing child abuse and neglect: a national evaluation of Parents Anonymous groups. Child Welfare. 2010; 89(6):43-62.

16. Scharer, K. Internet social support for parents: The state of science. J Child Adol Psych Nursing. 2005; 18(1):26-35. [DOI:10.1111/j.17446171.2005.00007.x] [PMID]

17. Davis-Groves S, Barfield ST, McCave E, Corrigan SK. Parent support: Building structures that support and assist children. School of Social Welfare, University of Kansas; $2007 . \quad$ Retrieved from http://www.socwel.ku.edu

18. Hartman AF, Radin MB, McConnell B. Parent-toparent support: a critical component of health care services for families. Issu Compr Pediat Nurs. 1992; 15(1):55-67. [DOI:10.3109/01460869209078240] [PMID]

19. Rosenberg AR, Dussel V, Kang T, Geyer JR, Gerhardt CA, Feudtner C, et al. Psychological distress in parents of children with advanced cancer. JAMA Pediatr. 2013; 167(6):537-43 [DOI:10.1001/jamapediatrics.2013.628] [PMID] [PMCID]

20. Lown EA, Phillips F, Schwartz LA, Rosenberg AR, Jones B. Psychosocial follow-up in survivorship as a standard of care in pediatric oncology. Pediatr Blood Cancer. 2015; 62(suppl 5): S514-84. [DOI:10.1002/pbc.25783] [PMID] [PMCID]

21. Ireys, HT, Chernoff R, Stein R, DeVet KA, Silver E. Outcomes of community-based family-to-family support: Lessons learned from a decade of randomized trials. Children's Services: Soc Policy, Res Practice. 2001; 4(4):201-6. [DOI:10.1207/S15326918CS0404 04]

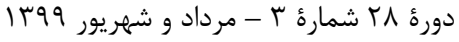

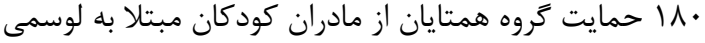

22. Sharif F, Abshorshori N, Tahmasebi S, Hazrati M, Zare N, Masoumi S. The effect of peer-led education on the life quality of mastectomy patients referred to breast cancer-clinics in Shiraz, Iran 2009. Health Qual Life Outcomes. 2010; 8(1):74. [DOI:10.1186/14777525-8-74] [PMID] [PMCID]

23. Ravens-Sieberer U, Bullinger M. Assessing healthrelated quality of life in chronically ill children with the German KINDL: first psychometric and content analytical results. Qual Life Res. 1998;7(5):399-407 [DOI:10.1023/A:1008853819715] [PMID]

24. Valizadeh L, Hosseinpour-Feizi AA, Joonbakhsh. F. Comparing the quality of life in children with cancer in Tabriz Children Medical and Training Center reported by themselves and their parents, 2013. J Clin Nurs Midwifery. 2014; 3(1):1-8.

25. Ramacher D. Parent peer support: impact on children with mental illness. J Student Res. 2011: 1-20.

26. Singer GH, Marquis J, Powers LK, Blanchard L, Divenere N, Santelli B, et al. A multi-site evaluation of parent to parent programs for parents of children with disabilities. J Early Interven. 1999; 22(3):217-29. [DOI:10.1177/105381519902200305]

27. Solomon M, Pistrang N, Barker C. The benefits of mutual support groups for parents of children with disabilities. America J Community Psych. 2001; 29(1):113-32.

[DOI:10.1023/A:1005253514140] [PMID]

28. Singer GH, Hornby G, Park J, Wang M, Xu J. Parent to parent peer support across the Pacific Rim. J Int Spec Need Edu. 2012; 15(2):89-106 [DOI:10.9782/2159-4341-15.2.89]

29. Han HR. Korean mothers' psychosocial adjustment to their children's cancer. J Advanc Nurs. 2003; 44(5):499-506. [DOI:10.1046/j.03092402.2003.02833.x] [PMID]

30. Bracke P, Christiaens W, Verhaeghe M. Self-esteem, self-efficacy, and the balance of peer support among persons with chronic mental health problems. J Appl Soc Psych. 2008; 38(2):436-59. [DOI:10.1111/j.15591816.2008.00312.x] 